\title{
CONTRADIÇÕES CAMPONESAS NO BRASIL
}

\section{PEASANTS CONTRADICTIONS IN BRAZIL}

\author{
João Edmilson Fabrini \\ Professor de graduação e pós-graduação em Geografia da Unioeste e UFGD \\ fabrini2@hotmail.com
}

\begin{abstract}
Resumo
A complexa trama de reprodução da classe camponesa no modo capitalista de produção está relacionada às contradições dessa classe. Os camponeses que, de um lado, derrubam cercas latifundiárias do agronegócio na sua luta pela reforma agrária, de outro lado, se posicionam politicamente a favor daqueles que são contrários às suas lutas. Verificam-se contradições também no âmbito familiar, que reforça valores humanos e solidários, mas reproduz o autoritarismo patriarcal. As contradições existem ainda na adoção, ou recusa, de tecnologias e conhecimentos aplicados à produção agropecuária.
\end{abstract}

Palavras-chave: Contradição. Reprodução Camponesa. Movimentos Sociais. Agronegócio. Família Camponesa.

\begin{abstract}
The complex reproduction pattern of the peasant class in the capitalist mode of production is related to the contradictions of this class. The peasants who, on the one hand, overthrow agribusiness landowners in their struggle for agrarian reform, on the other hand, are politically positioned in favor of those who are opposed to their struggles. There are also contradictions in the family, which reinforces human values and solidarity, but reproduces patriarchal authoritarianism. The contradictions still exist in the adoption, or refusal, of technologies and knowledge applied to agricultural production.
\end{abstract}

Keywords: Contradiction. Peasant Reproduction. Social Movements. Agribusiness. Family Peasant.

\section{Introdução}

Os camponeses possuem vigorosa capacidade de afrontar a dominação a engendrada no modo capitalista de produção, mas contraditoriamente, reproduzem relações sociais conservadoras e opressoras, enfim, negam e/ou reproduzem a estrutura e superestrutura dominante. As contradições camponesas podem ser verificadas quando, 
de um lado, os camponeses não hesitam em derrubar cercas de grandes propriedades rurais latifundiárias, por exemplo, e de outro, reproduzem concepções e práticas conservadoras como na esfera política eleitoral, quando se verifica, em muitos casos, um "voto conservador".

As contradições camponesas também ocorrem nas relações de produção quando adotam técnicas modernas em determinados de cultivos, de um lado, e arcaicas e "tradicionais", de outro. Não são raros os camponeses que fazem seleção de sementes e melhoramento genético artesanais, recuperação de práticas agrícolas erodidas no tempo, adubação orgânica, dentre outras, contudo, em outros contextos utilizam sementes híbridas, transgênicas ou selecionadas em laboratórios de corporações capitalistas globais.

Existem contradições camponesas também na esfera superestrutural e ideológica como nas relações familiares que, aliás, se constitui na centralidade da vida camponesa. A família camponesa reproduz padrões conservadores, autoritários, machistas, etc. Mas, tais famílias camponesas reproduzem gestos de solidariedade, bem como se constituem em base de organização dos movimentos sociais de luta pela terra.

Entretanto, observa-se que a atenção às contradições não implica em aversão à classe camponesa, pois a superação das contradições camponesas passa pelo fortalecimento dessa classe, e não pelo seu fim. Acrescenta-se que as contradições não são caraterísticas apenas da classe camponesa, mas também da classe trabalhadora, que em muitos casos, também reproduz a ideologia dominante.

\section{Contradições camponesas nas relações de produção}

As contradições camponesas se manifestam na esfera produtiva, quando de um lado, se adota técnicas e conhecimentos modernos para algumas atividades, e de outro, recorrem-se aos saberes e técnicas "tradicionais" e arcaicas para outras atividades. Os conhecimentos, saberes e técnicas do passado entre os camponeses não são resquícios ou vestígios que serão necessariamente removidos como o processo de modernização e expansão do modo de produção capitalista.

A adoção de técnicas modernas de cultivo entre camponeses está relacionada às transformações no padrão agrário e agrícola da agricultura brasileira. Segundo Silva (1996), essas transformações podem ser sintetizadas na concepção de complexo 
agroindustrial (CAI), o que implicou na implantação de uma racionalidade empresarial na produção agrícola, mesmo entre os pequenos agricultores, representada por uma agricultura integrada à indústria, com o surgimento de um agricultor profissional e especializado.

Segundo Silva (1996) ainda, a implantação do CAI desdobrou-se nas relações de trabalho, quando houve uma apuração ou purificação das relações com a emergência de uma classe trabalhadora mais definida. Acrescenta-se que na concepção do autor as tecnologias modernas aplicadas à agricultura tiveram rebatimentos superestruturais no modo de vida das populações camponesas com a adesão a costumes urbanos e alterações no padrão de consumo. As mentalidades e comportamentos urbanos foram sendo parcial e contraditoriamente adotados pela população camponesa.

Entretanto, as transformações no padrão agrário e agrícola não foram uniformes, pois se se verificou, de um lado, uma produção camponesa vinculada ao complexo agroindustrial, de outro lado, a manutenção, reprodução e recuperação de conhecimentos, práticas e saberes do passado, mantidos nos dias atuais pelos camponeses. A concepção de expansão contraditória das relações capitalistas de produção, tratada por autores diversos, tais como Luxemburgo (1988), Martins (1977), Oliveira (2010), dentre outros, fundamenta a desigualdade da modernização técnicaprodutiva da agricultura camponesa.

A adoção de técnicas e conhecimentos modernos é verificada em diferentes atividades, como a avicultura voltada para mercados globais, por exemplo, no qual os camponeses fazem uso de equipamentos altamente sofisticados de controle digital da temperatura dos aviários, sendo necessárias inclusive noções de língua inglesa para operacionalizar tais equipamentos. Mas, os mesmos camponeses avicultores modernos também praticam uma produção de autoconsumo a partir de técnicas, conhecimentos e ferramentas rudimentares como enxada, enxerto de plantas com um melhoramento genético artesanal, por exemplo. Observa-se, contudo, que a produção destinada ao consumo da família se comunica à produção de mercadoria, pois servem, em muitos casos, para baixar os custos de produção de valor de troca.

Ross (2015), ao tratar sobre "os assentamentos de reforma agrária no Centro-Sul do Paraná", exemplifica que, em região dominada pela silvicultura, os assentados têm encontrado possibilidade de renda com cultivo de pinos e eucalipto transgênicos nos 
seus lotes, cultura tipicamente de agronegócio. Mas, o autor observou que os mesmos assentados que introduzem espécies transgênicas de cultivo, também se dedicam à produção de alimentos, seleção artesanal (camponesa) de sementes, adubação orgânica, melhoramento genético de animais, dentre outros conhecimentos e técnicas artesanais que contribuem para sua manutenção no campo.

A produção de autoconsumo entre as famílias camponesas também são evidências de práticas e conhecimentos do passado reproduzidos contemporaneamente que servem para garantir a existência presente das famílias. Nesse contexto de produção de autoconsumo emergem as experiências e saberes camponeses relacionados à "agricultura ecológica", que não depende diretamente de insumos adquiridos no mercado capitalista, como a adubação verde; uso de matéria orgânica produzida nos lotes, como resíduos de produtos ou de beneficiamento da produção (a palha), largamente utilizados na produção agrícola nos lotes; seleção artesanal de sementes (sementes crioulas); e métodos naturais de combate às pragas. Essa "agricultura ecológica" não é necessariamente sinônima de "agroecologia", que se utiliza de conhecimentos e técnicas sofisticadas produzidas e integradas a redes globais de resistência.

Apesar de relacionada à dinâmica capitalista, a agricultura camponesa se constitui numa unidade econômica de produção que possui uma lógica produtiva diferenciada da empresa capitalista moderna, pois é regida pelas necessidades de consumo e sobrevivência do grupo familiar. Diferentemente de produção moderna empresarial e despersonalizada, a família, enquanto unidade econômica de produção, é indicativa de relações sociais não-modernas. Acrescenta-se que a unidade econômica de produção familiar está pautada pelo pressuposto do balanço trabalho-consumo, como apontado por Chayanov (1974).

A produção familiar camponesa inclusive vai à contramão da produção coletiva enquanto alternativa gestada no contexto moderno de relações sociais de produção. Os camponeses recusam as cooperativas agrícolas coletivas, por exemplo, forjadas semelhante à uma fábrica, estranhas ao seu mundo familiar e comunitário.

Entretanto, os camponeses possuem capacidade de produção associativa. Os associativismos na esfera produtiva entre os camponeses ocorrem mediados pelo seu espaço local comunitário como as trocas solidárias de trabalho (dias de serviço), 
produtos, sementes, alimentos, conhecimentos e técnicas de cultivos, utilização de máquinas, ferramentas, serviço de transporte, enfim, numa variedade de trocas realizadas não reguladas por relações mercadológicas. Ainda no âmbito comunitário, as feiras de sementes são atividades recentes que se tornaram comuns entre os camponeses e também são importantes experiências de resistência camponesa.

As atividades comunitárias, caracterizadas pela solidariedade, ocorrem geralmente nos momentos de precisão (necessidades) e estão relacionadas à sociabilidade forjada na esfera da vizinhança e do espaço próximo (local), como afirma Martins (2002): "a consciência do camponês expressa a consciência da pessoa, que é extensão da família e da comunidade e dos laços comunitários" (p.75).

As relações e atividades comunitárias são caracterizadas mais por vínculos de solidariedade entre as pessoas do que por revelações políticas e ideológicas classistas modernas. Observa-se, no entanto, que os laços comunitários podem ser potencializados e se desdobrar em manifestações coletivas. Santos (1978), em estudo sobre os "colonos do vinho", no Rio Grande do Sul, refere-se às práticas de construção da utopia comunitária como ajuda mútua, festa, religião, entre outros. Estas formas de relações permitem um ordenamento social que leva às manifestações politizadas de cidadãos que reivindicam medidas do Estado no atendimento de seus interesses e formação de uma "consciência sindical".

Portanto, verifica-se que os camponeses reproduzem relações de produção do passado, como a manutenção de produção para autoconsumo, trocas solidárias, relações comunitárias mediadas pela família, vizinhança, dentre outras. Mas, como destacado anteriormente, no contexto contraditório e desigual das relações sociais de produção capitalista, os camponeses estão inseridos no mundo moderno e utilizam-se de conhecimentos e técnicas modernas forjadas em fábricas e laboratórios científicos de empresas capitalistas. Além das contradições camponesas na dimensão produtiva e tecnológica, tais contradições se manifestam também na dimensão social, política, entre outras.

\section{Contradições camponesas na dimensão política}

As contradições são verificadas também na dimensão política quando, de um lado, os camponeses tomam decisões questionadoras e críticas à estrutura e 
superestrutura da sociedade, e de outro, conservadoras. A organização dos camponeses nos movimentos sociais de luta pela terra e reforma agrária é evidência de ação política questionadora e crítica.

A interpretação hegemônica das ações políticas dos camponeses foi norteada pelo seu papel na revolução socialista, ou seja, a partir da possibilidade de sua participação nos processos revolucionários que foram formuladas concepções teóricas e políticas sobre o campesinato. Karl Marx tratou da classe camponesa em vários textos políticos como "Formação Econômica Pré-Capitalista" e "18 de Brumário", quando buscou entender o papel das "forças retardatárias", no caso, o campesinato, no processo revolucionário socialista. Essa preocupação ficou evidente também no questionamento feito por Vera Sazulitch, liderança populista russa do final do século XIX, se era possível revolução e socialismo entre os camponeses do Mir russo.

Segundo Vianna (2014), Marx deixou evidente em "O Capital”, que não havia possibilidade de existência camponesa com a expansão do capitalismo. Marx, na Contribuição à Crítica da Economia Política, entendeu que a transição para o socialismo será obra do moderno, ao afirmar que "nenhuma formação social desaparece antes que se desenvolvam todas as forças produtivas que ela contém".

\footnotetext{
A transição para o socialismo seria, nessa versão, obra do moderno e dependente de uma plena maturação do capitalismo, construção teórica escorada em textos do próprio Marx, como no prefácio de 1859 à Contribuição à Crítica da Economia Política, quando sustentou que "nenhuma formação social desaparece antes que se desenvolvam todas as forças produtivas que ela contém". (VIANNA, 2014, p. 1. Grifo do autor).
}

Hobsbawm (1999) visualizou nas ações coletivas dos camponeses uma política primitiva. Os vínculos dos camponeses com a propriedade da terra e seu projeto individualista familiar foram entendidos como portadores de conteúdo conservador que visava manter estruturas sociais desiguais e hierarquizadas a partir da apropriação dos meios de produção. Segundo o autor ainda, a política (pré-política) dos camponeses é conservadora porque está vinculada a um microcosmo fragmentado e parcial, não havendo possibilidade de um movimento nacional, amplo e abrangente, sendo mais provável um movimento estimulado de fora; de cima para baixo.

A dificuldade dos camponeses se situarem politicamente estaria relacionada à sua inserção na sociedade de classes, uma vez que não era um operário (proletário) nem um capitalista (burguesia). Numa sociedade de classes dividida entre "escravo e senhor", ou 
"operário e burguesia", como a brasileira, não havia lugar social para o campesinato e a possibilidade de projeção política. Assim, os camponeses, em vista de sua condição de classe, foram entendidos como se não tivessem projeto de totalidade. Seu projeto e lutas são pela busca de benefícios individuais, imediatos e localizados.

Segundo Vladimir Lênin, tendo por base o desenvolvimento desigual e combinado, as "forças retardatárias" possuíam papel político ativo, quando foi cunhada na idéia de aliança operário-camponesa. A revolução não seria um processo linear e poderia ocorrer em saltos, o que foi confirmado em 1917, quando um país agrário realizou a primeira revolução socialista. Mitrany (1957) entendeu que a revolução de 1917 foi camponesa, mas que os bolchevistas apoderaram e a organizaram do seu jeito na Rússia. Além da russa, muitas outras revoluções camponesas foram realizadas no século XX, conforte destacou Wolf (1984) como a revolução mexicana, cubana, dentre outras, etc.

Mas, os camponeses, organizados nos movimentos sociais, têm demonstrado capacidade de ação política moderna e questionadora de estruturas sociais. A organização deles nos movimentos sociais permite revelações políticas que indicam compreensão do ordenamento da sociedade de classe opressora e oprimida a partir da apropriação dos meios de produção em que, de um lado, estão os capitalistas, e de outro, os trabalhadores e camponeses. Por meio dos movimentos sociais os camponeses se voltam para o Estado ao exigirem políticas públicas, por exemplo, que se contrapõe a política de favor, clientelismo e dependência de um "coronel" do local.

Os movimentos sociais são manifestações organizadas da sociedade civil com o objetivo de contestar a ordem estabelecida e a maneira como a sociedade está organizada. Eles estão presentes na luta por grandes transformações da sociedade, tais como a luta por mudanças na estrutura fundiária, bem como reivindicações localizadas e ligadas à cidadania, garantia de direitos. Essas características também contribuem para inscrever os movimentos sociais camponeses na perspectiva da modernidade; da política dos modernos.

Scherer-Warren (1999) estabelece um quadro de referências para tratar daquilo que considera "ações coletivas" dos movimentos sociais rurais, sintetizado nos enfoques "estruturalistas" e "culturalistas". O enfoque estruturalista se firma em ação política macro-fundamentada em torno da negação da estrutura fundiária concentrada e 
processos produtivos, por exemplo. Os sujeitos coletivos são definidos por categorias abrangentes, como campesinato, proletariado, indígenas, entre outros.

O enfoque culturalista é fundamentado sócio-culturalmente e enfatiza uma lógica de mobilização coletiva a partir de relações sociais cotidianas e vinculadas a identificações culturais como feministas, ecológicos, raciais, juvenis, etc. A pauta de reivindicação culturalista, como as identidades culturais, pode indicar inclusive um sentido pós-moderno dos movimentos sociais. Assim, a organização dos sujeitos vinculados à cultura e à identidade, e não diretamente à classe e ao trabalho, poderá ser indicativa dessa dimensão pós-moderna.

O caráter crítico e questionador à ordem social dos camponeses organizados nos movimentos pode ser verificado ainda na formação de rede de relações, inclusive virtuais. A criação de redes de movimentos sociais possibilita a difusão de ideal democrático conectando as filosofias locais ao global, e vice-versa, em que questões do cotidiano se tornam globais e planetárias. Por meio da rede pode se alcançar a interação à diversidade numa relação mais democrática, horizontal e plural, conectando diferentes espaços e tempos históricos.

Os movimentos sociais permitem aos camponeses estabelecer relações políticas, sociais e produtivas em redes mundializadas. Mas, tais redes se diferenciam das capitalistas porque não estão pautadas na mundialização (globalização) do mundo da mercadoria. Aliás, as redes camponesas visam solapar a ordem do mercado global capitalista numa ação antiglobalização do capital. São exemplares as ações da La Vía Campesina, um movimento camponês internacional antiglobalização.

A formação e o fortalecimento de "entidades" mundializadas são entendidas por alguns autores como uma alternativa de organização e resposta ao processo de globalização do capital. Trata-se também de uma resposta em escala mundial assentada em amplas alianças entre os diferentes sujeitos organizados em movimentos sociais populares.

[...] temos de procurar uma articulação dos excluídos, desprezados, dominados e explorados em escala mundial, incluindo os que vivem nos países desenvolvidos; uma coordenação, cooperação e alianças entre os sujeitos políticos e sociais que participam nas lutas emancipadoras procurando a construção de entidades mundiais. É necessário elaborarmos uma estratégia que inclua a articulação com forças que operam nos três grandes blocos de poder mundiais, e estabelecer relações multilaterais com cada um deles como uma maneira de deslocar a partilha política das zonas de influência entre os mesmos. (HARNECKER, 2000, p. 393). 
Os movimentos camponeses, embora se nutrindo politicamente do território (local), têm valorizado as ações em escala ampla e massiva como a realização de grandes encontros, marchas, eventos e manifestações variadas que criam um fato político e garantem grande repercussão. As pequenas manifestações localizadas acabam sendo depreciadas, sendo as lutas consideradas isoladas, não portadoras de potencial transformador da sociedade.

Os vínculos políticos dos camponeses organizados nos movimentos sociais possuem também um caráter pedagógico e educativo. Caldart (2000), ao tratar da pedagogia do movimento, no caso o MST, refere-se ao camponês sem-terra que se educa no processo de luta como um "novo" camponês, que, ao se transformar neste processo, supera a condição do "antigo" camponês.

De novo é preciso dizer que a cabeça do antigo camponês ou boia-fria, vira de ponta cabeça, e uma nova visão de mundo aos poucos vai sendo construída, sempre na relação com tradições que continua carregando, seja como complemento, como contradição ou já como síntese. (CALDART, 2000, p. 118).

Assim, os movimentos sociais tornaram-se paradigmáticos nas lutas, resistências e construção do lugar social dos camponeses. Mas, ao se construir paradigmáticos, os movimentos não devem ser absolutizados ou considerados de forma exclusiva, como se tivessem o monopólio do exercício da política. A política na esfera institucional, como o partido e o sindicato, por exemplo, é um importante meio de participação que se cruza com a ação política nos movimentos camponeses.

Além de questionadores à estrutura social, os movimentos camponeses também possuem um sentido de modernização política, ou seja, são uma expressão política moderna. A reforma agrária, dentre outros exemplos, como soberania nacional alimentar, globalização neoliberal, democracia, políticas públicas, ambiente, gênero, homofobia, dentre outros, são temas da modernidade política.

$\mathrm{Na}$ compreensão dos movimentos camponeses a reforma agrária possui também um sentido desenvolvimentista, pois a capacidade produtiva camponesa teria papel importante para a nação, inclusive de soberania, no caso alimentar, e não apenas um benefício para os camponeses. Assim, o lugar social dos camponeses e da pequena agricultura seria garantido pela sua eficiência e capacidade produtiva de alimentos e matérias-primas para atender às demandas da nação brasileira ${ }^{1}$. 
Essa concepção de reforma agrária para o desenvolvimento nacional, guardadas as diferenças, também é compartilhada pela Comissão Econômica Para a América Latina e Caribe (Cepal). Para a Cepal há necessidade de mudanças na estrutura agrária altamente concentrada com realização de reforma agrária para o Brasil (e nações subdesenvolvidas) alcançar a industrialização e o desenvolvimento.

A luta e defesa da reforma agrária a partir dos movimentos camponeses permitem superar a acumulação rentista absoluta, indicativa de relações arcaicas, que dão sustentação a uma oligarquia rural, muitas vezes travestida de agronegócio produtivo, presente contemporaneamente no espaço agrário brasileiro. Assim, os movimentos camponeses na sua luta pela reforma agrária estão em contraposição à ordem latifundiária oligárquica do "velho rural" rentista.

Além desse conteúdo questionador moderno dos movimentos sociais, os camponeses têm capacidade de solapar estruturas de dominação a partir de canais conservadores como a religião, por exemplo. A política arcaica dos camponeses muitas vezes é aparentemente conservadora, pois na essência possui um conteúdo questionador e transformador que a razão iluminista da política dos modernos não consegue compreender.

Segundo Martins (1989), a política conservadora dos camponeses possui uma lógica que os estudiosos não conseguem interpretar com seus instrumentos teóricos marxistas. Estes chegam tarde à luta camponesa e quando chegam procuram tutelar ideológica e politicamente o movimento e luta dos camponeses.

\footnotetext{
De um lado, a luta no campo não nasce politizada. De outro lado, os partidos e "tendências" chegam ao campo, quase sempre, muito depois das lutas iniciadas, com outras motivações, procedentes de um projeto revolucionário derrotado. Chegam, passivamente, tentando instrumentalizar e aparelhar organizações existentes, como a Igreja e o sindicato, disputando delas a hegemonia política sobre os trabalhadores... Até mesmo para 'segurar' e disciplinar ou dirigir a luta no campo, com base em teorias quase sempre produtivas a partir de outras realidades sociais e históricas, como do papel condutor da classe operaria na revolução ou a do papel condutor do campesinato na revolução. (MARTINS, 1989, p. 70).
}

Essa política dos movimentos sociais camponeses, exercida fora do partido, sindicato ou Estado e realizada em tempos desencontrados, é visualizada por Martins (1989) como portadora de conteúdo libertário. Trata-se de uma prática política conservadora que é questionadora e libertadora que não é feita pelos canais 
institucionais que os "agentes" políticos, teóricos e religiosos, muito vezes não reconhecem.

\begin{abstract}
"Esse quadro sugere a necessidade de uma mudança de perspectiva: a de pensar o camponês como inovador, exatamente o oposto de quem tem isso pensado. Essa mudança, porém, não deve levar à ingenuidade de supor que a tradição e a cultura tradicional já não têm importância no campo, já não pesam nas decisões e nos acontecimentos. O caminho para refletir sobre o tema é o de examinar as transformações que modificam velhas relações sociais que atenuam ou destroem a autoridade da cultura tradicional e que abrem espaço para a invenção cultural... É nessa contraposição que se movem os trabalhadores rurais em sua luta e é por ela que se pode compreender o sentido da fala nova, do gesto novo, da canção nova, das formas modificadas de sociabilidade que podem ser encontradas por todas as partes, de quarentas anos para cá e, sobretudo, nos últimos vinte anos". (MARTINS, 1989, p.18).
\end{abstract}

Conforme Martins (1989, p. 117), a ação política dos camponeses é uma resistência subterrânea verificada na ironia, dissimulação metafórica não explicada pela modernidade. O autor exemplifica o caso de Galdino Jacinto, que formou um grupo de resistência denominado "exército divino" e foi condenado pela Justiça Militar porque expressava politicamente pelo gesto "inadequado" do sorriso, dissimulação, movimento inadequado e fora de hora das mãos, considerado perigoso pela visão moderna da Justiça e da Psiquiatria.

Mas, contraditoriamente, em contraponto à visão linear das relações sociais de produção, a existência camponesa também é perpassada intrinsecamente por ações políticas arcaicas e conservadoras. Assim, verifica-se que se os camponeses são questionadores, eles também reproduzem estruturas de dominação tanto na sua ação política moderna (movimentos sociais) quanto arcaica. Aliás, os próprios movimentos camponeses enquanto expressão política moderna reproduz traços conservadores do ponto de vista político.

Observa-se, por exemplo, na política eleitoral brasileira um "voto conservador", inclusive por aqueles camponeses vinculados aos movimentos sociais que possuem trajetória de luta pela reforma agrária, por exemplo. Os camponeses de assentamentos de reforma agrária que possuem essa trajetória de resistência a partir dos movimentos sociais votam, muitas vezes, em candidatos contrários à reforma agrária e luta pela terra, muitos deles vinculados ao agronegócio latifundiário ${ }^{2}$. Os camponeses, como os semterra, por exemplo, que não hesitam em derrubar as cercas latifundiárias do agronegócio latifundiário, reproduzem estruturas de dominação ao se posicionar politicamente em 
eleições, ao lado daqueles que lhes prejudicam e tomam decisões contrárias às suas demandas.

Os camponeses sem-terra vinculados ao MST ainda, quebram com "punho erguido", por meio das ocupações de terra, as cercas excludentes e violentas do latifúndio, o que inspirou inclusive Dom Pedro Casaldáliga, bispo da Igreja Católica da prelazia de São Felix do Xingu (MT), a afirmar que "maldita sejam todas as cercas". Mas, os camponeses que quebram as cercas latifundiárias do agronegócio, defendem e empunham a bandeira da cerca, ou seja, a cerca camponesa da terra, sugerindo que nem todas as cercas são malditas. Portanto, é uma ilusão movida pelo igualitarismo coletivista científico ou cristão, condenar todas as cercas na apropriação da terra, considerando que os camponeses têm no seu projeto de existência o estabelecimento de cerca da terra familiar.

É ilustrativo também o caso de camponeses, sobretudo na região Sul do Brasil (pequenos agricultores do Rio Grande do Sul e do Paraná), que se somam ao agronegócio para combater as ações de retomada de terra dos indígenas. Ainda no Sul do Brasil, muitos camponeses estão aliados ao agronegócio e à bancada ruralista na luta para cancelar a resolução do Conselho Monetário Nacional que estabelece progressivamente que os fumicultores, para acessar recursos do Pronaf (Programa Nacional de Fortalecimento da Agricultura Familiar), devem comprovar que ao menos $30 \%$ da sua renda vêm de outras culturas que não o tabaco. A prática da fumicultura pelos camponeses no Sul, onde se encontram 91\% dos produtores de tabaco do Brasil, contraria conjunturalmente a ideia de camponês produtor de alimentos.

Nesse sentido, verifica-se um conteúdo conservador, não sendo raros os pequenos agricultores que se somam às organizações do agronegócio, como CNA (Confederação Nacional da Agricultura), no combate à luta dos sem-terra, quilombolas, etc. Assim, contraditoriamente, a classe camponesa reforça politicamente a estrutura desigual e excludente capitalista, mas também questiona a partir de uma ação política moderna dos movimentos sociais, as desigualdades sociais. Além das contradições camponesas na esfera política e produtiva, verifica-se essa contradição também nas relações sociais. 


\section{Contradições camponesas nas relações sociais}

Além das contradições camponesas relativas à estrutura econômico-produtiva e política, como destacado anteriormente, verifica-se contradições camponesas do ponto de vista superestrutural e cotidiana, ou seja, nas relações de gênero, étnicas, costumes, culturais, dentre outras.

A reprodução de violências ${ }^{3}$ a que os camponeses estão submetidos é exemplo de contradições nas relações sociais e cotidianas. Os camponeses, ao serem vítimas de violência de classe, como nos conflitos com latifundiários do agronegócio, por exemplo, a reproduzem na esfera cotidiana e interna à classe como se o oprimido também fosse um opressor.

As violências vinculadas à classe são ressignificadas e reproduzidas cotidianamente pelos camponeses, como demonstrou Silva (1999) em estudo sobre "código do sertão". A autora observou entre os oprimidos (camponeses do Vale do Jequitinhonha que migraram para a região de Ribeirão Preto) uma violência cotidiana semelhante àquela praticada pelos opressores. São violências reproduzidas pelos camponeses a partir do código dos dominantes, no caso, código dos detentores da propriedade da terra, tendo a grilagem e disputa de terra, enfim, tendo uma dimensão de classe como "pano de fundo".

Silva (1999) observou também que a violência cotidiana entre os camponeses não é motivada somente pelo conflito de classe, mas também pela dimensão de gênero e raça/etnia, ou seja, por padrões de conduta geridos pela ordem costumeira, pelo "código do sertão", normas não escritas das relações pessoais. São violências internas à classe que geralmente não ameaçam diretamente o poder político do coronel ou empresário, como a violência motivada por embriaguez, briga entre parentes, motivos amorosos, estupro, herança, posse de terra, gênero, dentre outros, praticada muitas vezes em nome da valentia e coragem como principais elementos do "código do sertão".

A violência de gênero também está colocada como parte das características dos camponeses que passa pelas relações patriarcais de afirmação e dominação sobre o outro, no caso as mulheres, vítimas de homens que também são vítimas. Muitas 
violências entre camponeses ocorrem por disputa de mulheres consideradas como bens, sendo a valentia do macho forte um caminho para possuí-la.

Segundo Silva (1999) ainda, as violências entre camponeses são movidas também pela defesa de sua imagem, honra e para manter a fama e importância, na busca de auto-afirmação e autodeterminação com violência costumeira entre irmãos, parentes, amigos e conhecidos em nome da honra, demonstrando imagem de coragem e valentia. Tais violências são manifestadas em espaço público, lúdico e diversão, como festas e bailes, momento para reconhecimento e afirmação do poder e valentia.

Nesse contexto, os versos de Teddy Vieira e Sebastião Victor, essencialmente vinculados ao universo rural camponês, são ilustrativos para demonstrar violência cotidiana e interna à classe, no caso interna aos camponeses:

\footnotetext{
Conheci o Zé Mariano, um home sem coração

Na Arta Sorocabana foi o rei dos valentão

Com mais de cinqüenta morte era o terror do sertão

Nas festas que ele chegava matava sem compaixão.

Certo dia numa venda, veja o que ele foi fazê

Tirou seu punhár da cinta e não deixou ninguém corrê

Pegou um garrafão de pinga e obrigou o pessoar bebê

No meio tinha um menino que não quis obedece.

Mariano virou e disse, menino de onde veio?

Moleque você vai bebê um copo grande bem cheio

Aquele que se doê pode falá sem receio

Home de barba na cara costumo cortá de reio.
}

Além da reprodução de violência externa e interna à classe em que o oprimido também é opressor, outro exemplo que indica contradições camponesas na esfera das relações sociais é a natureza dos seus laços familiares. A família camponesa, contraditoriamente, apresenta tanto traços críticos à estrutura social, quanto conservadores e arcaicos, enraizados desde passado distante. Portanto, em torno da instituição familiar, podem-se verificar contradições no sentido de apresentar-se conservadora ou negadora de estrutura de classes, dominação, preconceito e desigualdades diversas.

\section{A família camponesa}

A agricultura camponesa é essencialmente familiar. A família se constitui numa instituição que desenvolve laços sociais, biológicos, afetivos, emocionais, jurídicopolítico, dentre outros, e foi denominada por segmentos diversos como célula básica da 
sociedade. A família é capaz de reproduzir valores humanos, solidários e igualitários, o que permitiu a Organização das Nações Unidas (ONU) a defini-la como "pequena democracia no coração da sociedade". Mas a família também é uma instituição que reforça concepções conservadoras, autoritárias, preconceituosas e violentas, ou seja, reproduz relações sociais de dominação e opressão.

Engels (1984), ao tratar da origem da família (na sua relação com o Estado e propriedade privada), afirma que ela possui diversos tipos, a exemplo da família poligâmica, poliândrica e monogâmica. Acrescenta-se na formação familiar, desde passado distante, as diferentes relações conjugais consanguíneas, pais, filhos, mulheres comuns de seus maridos, primos, dentre outros.

São exemplares nos estudos de Engels (1984) os matrimônios em grupos, no estádio selvagem; os sindiásmicos na barbárie; e os monogâmicos, no período civilizado (p. 81). Verifica-se ainda que existiu uma forma de família, hoje extinta, com diferentes relações de parentesco, em que cada filho tinha vários pais e mães. Acrescenta-se a prática da poligamia e poliandria, em que os filhos de uns e de outros eram comuns.

De uma rica família de origem índia, refere Agassiz... que, tendo conhecido a filha da casa, perguntou-lhe por seu pai, supondo que seria o marido de sua mãe, oficial do exército em campanha contra o Paraguai; mas a mãe lhe respondeu, com um sorriso: "não tem pai, é filha da fortuna". As mulheres índias ou mestiças falaram sempre neste tom, sem considerar vergonhoso ou censurável, de seus filhos ilegítimos; e essa é a regra, ao passo que o contrário parecer ser a exceção. Os filhos [...], amiúde conhecer apenas a mãe, porque todos os cuidados e todas as responsabilidades recaem sobre ela; nada sabem a respeito do pai, nem parece possa ocorrer à mulher a ideia de que ela ou seus filhos tenham o direito de reclamar dele alguma coisa. (ENGELS, 1984, p. 54).

Engels (1984) afirma ainda que entre indígenas americanos dos Estados Unidos havia um matrimônio facilmente dissolvido entre as partes, denominado de família sindiásmica. Existia também o caso da família punaluana, com casamentos por grupo ou classe, em que o homem de um grupo era marido de todas as mulheres, como o Grupo Kroki e Komite, na Austrália. Aí se estabeleciam diversos graus de parentesco em que não se podia saber que é o pai de uma criança, apenas a mãe. No caso da família sindiásmica, um homem ou mulher vive com o cônjuge principal e possui outros homens ou mulheres, mas geralmente era a mulher que devia fidelidade ao homem.

Outro tipo de família que recebeu atenção de Engels (1984) foi a monogâmica, sendo aquela que implicou no estabelecimento de laços conjugais mais sólidos. A família monogâmica iniciou-se como "organismo" social em que o chefe (homem) 
possuía poder de vida ou morte sobre mulher, filhos e escravos, o que deu origem ao pátrio-poder. A família monogâmica está baseada no predomínio do homem e se expressa na finalidade de procriar filhos com paternidade indiscutível porque os filhos serão os herdeiros diretos dos bens do pai.

A monogamia não teve origem no amor sexual, mas a partir de uniões (casamento) de conveniência motivadas pela propriedade a ser herdada, ou seja, uma família baseada em condições econômicas. Os casamentos burgueses, por exemplo, passavam por arranjos guiados pelo patrimônio e pela classe a que homem e mulher pertenciam, ou seja, um matrimônio de classes.

Ainda segundo Engels (1984), a família monogâmica está relacionada à definição dos papéis e divisão do trabalho entre homem e mulher. As mulheres assumiram papel nos tratos domésticos e a supremacia da casa - semelhante à ideia de rainha do lar - e os homens assumiram o trabalho produtivo. Coube à mulher, no máximo, um papel auxiliar ao trabalho produtivo do homem. Essa divisão de trabalho colocou a mulher numa condição secundária, ou seja, a condição secundária da mulher estava diretamente relacionada à divisão e à realização do trabalho.

Verifica-se assim que a família monogâmica não é uma instituição surgida a partir de leis divinas, semelhante a uma família sagrada. É família originada no contexto de produção que se tornou dominante na Europa e que se estendeu na esteira do processo de expansão colonial do século XVI, em que se inclui a "família brasileira" e suas especificidades. A família brasileira monogâmica, nascida essencialmente rural, está inserida nesse contexto produtivo e apresenta traços gerais autoritários, repressivos e reprodutores de normas de controle social.

Existem diversos "olhares" para a família rural brasileira, desde os estudos feitos numa perspectiva cultural, como os de Fukui (1979), por exemplo, bem como a abordagem da família camponesa na perspectiva de classes que considera o seu papel na revolução socialista. Relacionada a essa perspectiva de classe, a família camponesa foi visualizada a partir da subordinação ao capital e ao processo de expropriação/exploração a que está submetida, bem como os enfrentamentos e suas estratégias de resistência, existência e reprodução social.

Antonio Cândido (2003), enfocando a família caipira (camponesa) como unidade mínima econômica e social a partir do "bairro rural", afirma que ela é uma 
organização patriarcal que apresenta comportamentos "tradicionais". Mas, considera que a família camponesa não está congelada no tempo, pois a modernização, industrialização e urbanização provocam mudanças e transformações diversas na estrutura da família do bairro rural.

O estudo de Chayanov (1974) sobre a unidade econômica campesina se constituiu paradigmático ao colocar a família na base da agricultura camponesa, pois toda a sua existência está organizada em torno do núcleo familiar. É possível apreender, a partir de Chayanov (1974), que a família camponesa se constitui numa unidade econômica baseada na relação trabalho-consumo que se desdobra social, política, cultural e territorialmente.

A centralidade da família na agricultura camponesa levou muitos órgãos governamentais, movimentos sociais, intelectuais, dentre outros, reconhecerem a existência de uma "agricultura familiar". A concepção de "agricultura familiar" emergida no Brasil a partir do estudo de Abramovay (1992), principalmente, deslocou o centro de interpretação da agricultura camponesa a partir da família para a produção de mercadorias. Portanto, o conceito de "agricultura familiar" colocou a produção de mercadorias, e não o atendimento da necessidade no balanço trabalho-consumo, como no estudo de Chayanov (1974), no centro da interpretação e existência da pequena agricultura.

A Família Camponesa no Brasil possui características essencialmente patriarcais forjadas em passado distante, que remonta o período colonial, o que confere um conteúdo conservador a essa instituição. Forjada no período colonial, a família patriarcal era uma necessidade do sistema erguido a partir da escravidão e constituía-se numa unidade econômica, social, política, jurídica, etc. Assim, a família patriarcal se explicava pela estrutura colonial agrária, pois o modo de produção demandava de uma família extensa que envolvesse, sob comando do chefe, esposa, filhos, parentes, agregados, escravos, dentre outros.

A família patriarcal (...) se instala nas regiões onde foram implantadas as grandes unidades agrárias de produção - engenhos de açúcar, fazendas de gado ou de plantações de café -, mantém-se através da incorporação de novos membros, de preferência parentes, legítimos e ilegítimos, a extensos "clãs" que asseguram a indivisibilidade de seu poder, e sua transformação se dá por decadência, com o advento da industrialização e a ruína das grandes propriedades rurais, sendo substituída pela "família conjugal moderna". (CORREAA, 1981, p. 6). 
A família patriarcal no período colonial era uma organização social semelhante a uma monarquia privada. A ausência do governo português no Brasil colonial era preenchida pela família patriarcal, sendo que o chefe da família possuía poder político para além dessa instituição, com a função de proteção e justiça. A vingança, por exemplo, era expressão dessa justiça no âmbito da instituição familiar. O fortalecimento e presença do Estado, posteriormente, desdobraram-se na diminuição do poder privado patriarcal, embora os traços desse poder estejam presentes contemporaneamente.

$\mathrm{Na}$ família patriarcal a mulher é institucionalmente vista como incapaz, tendo que ser tutelada pelo marido. Nessa família, mesmo considerando a complexidade das diferentes variações no espaço geográfico brasileiro, a mulher era (e ainda é em muitos casos) educada para cumprir seu papel de mãe de cuidar dos filhos, sendo boa mãe e mulher prendada. Ao homem cabiam as atividades fora de casa.

A formação da família patriarcal, geralmente monogâmica para as mulheres, não tinha origem no amor sexual e afetivo, sendo comum o casamento de conveniência, motivado pela propriedade a ser herdada, ou seja, uma família baseada essencialmente em motivações econômicas. No período republicano os ideais burgueses emergiram desdobrando-se na instituição do casamento (formação das famílias), por exemplo, que passou a ser expresso na forma de contratos entre partes iguais. A liberdade e igualdade de condições permitiam a contração de matrimônio, ou seja, um casamento feito como um contrato, acordado geralmente entre os pais dos noivos com arranjos guiados pelo patrimônio e pela classe a que homem e mulher pertenciam. Embora fosse regra o casamento como um contrato entre partes, havia também casamentos monogâmicos entre as classes oprimidas, constituídos também a partir de uma base classista.

A urbanização e industrialização brasileira a partir da década de 1950 impactaram na estrutura patriarcal da família que não se ajustava ao novo contexto social urbano-industrial. Emergiu uma família conjugal moderna. Essa família moderna deixou de ser o núcleo do processo produtivo, sendo substituído pela empresa, ou seja, um ordenamento produtivo/econômico impessoal, com desdobramento no enfraquecimento dos laços de parentesco. Nesse contexto moderno urbano-industrial a família tornou-se uma instituição erguida e caracterizada mais por valores afetivos, coabitação, intimidade, vida no lar e sentimentos do que pela economia, embora essa não tivesse perdido o seu papel na constituição familiar. 
Acrescenta-se a esse contexto a migração da população do campo para cidade, culminando na "urbanização da família". Essa nova configuração familiar moderna foi motivo de preocupação da Igreja, que visualizava o solapamento dos valores nucleadores da família como uma instituição divina. A ideia é que a urbanização estava desenraizando as pessoas da família, promovendo o individualismo e destruindo as suas bases tradicionais de formação.

Conforme Engels (1984), essa família moderna e urbanizada, erguida a partir do contexto econômico industrial, possui maior potencial de emancipação; é uma família mais livre. Segundo o autor, a condição secundária e auxiliar da mulher, por exemplo, cristalizada desde a passagem da barbárie à civilização, quando as mulheres assumiram papel no trato doméstico e a supremacia na casa, será superada com sua entrada no processo produtivo econômico industrial. $\mathrm{O}$ processo econômico-industrial e a urbanização solaparam a estrutura da família como uma unidade econômica.

Nesse sentido, para autor, a emancipação da mulher ocorrerá quando ela deixar o trabalho confinado do lar em segundo plano para realizar o trabalho produtivo social, ou seja, quando a família deixar de ser uma unidade econômica doméstica e seus membros forem inseridos numa unidade econômica industrial de trabalho social.

\begin{abstract}
“A emancipação da mulher só se torna possível quando ela pode participar em grande escala, em escala social, da produção, e quando o trabalho doméstico lhe toma apenas um tempo insignificante. Essa condição só pode ser alcançada com a grande indústria moderna, que não apenas permite o trabalho da mulher em grande escala, mas até o exige, e tende cada vez mais a transformar o trabalho doméstico privado em uma indústria pública”. (ENGELS, 1984, p. 182).
\end{abstract}

De acordo com Engels (1984), a libertação da mulher ocorrerá com "a supressão da família individual enquanto unidade econômica da sociedade" (p. 81), pois o primeiro antagonismo de classes que apareceu na história foi o antagonismo entre o homem e a mulher. A primeira opressão foi a partir do sexo, ou seja, do sexo masculino sobre o sexo feminino, já que "na família o homem é o burguês e a mulher representa o proletariado" (p. 80).

Mas, os modelos de "família patriarcal rural" do período colonial e "família moderna urbano-industrial" se constituem numa generalização que não abarca a complexidade da instituição familiar. Segundo Correa (1981, p. 4) essa visão (generalizante) da família retira do horizonte outras organizações familiares, pois não reconhece as contradições e diversidades da família. Portanto, "família patriarcal 
agrária" ou "urbanizada-moderna" não são vias de mão única, uma vez que no seu interior se reproduzem contradições e conteúdos diversos, com inúmeras possibilidades de organização familiar, sendo que tais modelos não são suficientes para caracterizar a família brasileira.

Ainda conforme a autora, a família patriarcal colonial, ordenada a partir do latifúndio/exportação/escravidão, não estava restrita à casa grande, bem como o modelo urbano/industrial/assalariado não está exclusivamente vinculado ao mundo da fábrica e da cidade. Se no passado uma diversidade de família emergia conjugada contraditoriamente à família patriarcal colonial, nos dias atuais, a família moderna do período urbano-industrial, embora hegemônica, também não é único modelo.

Para além dos modelos hegemônicos de família (patriarcal agrária e modernourbanizada) existiam outras formações familiares, como é o caso das famílias ilegítimas, concubinato, agregados, mulheres e homens que vivem nas fímbrias do sistema, dentre outros. Acrescenta-se à complexidade e à diversidade de formação familiar aqueles jovens começam a viver juntos sem casamento; adultos que se divorciam; homens que compartilham com as mulheres a autoridade na família, inclusive, em muitos casos, cuidam dos filhos e do lar; filhos de relações anteriores convivendo com famílias recompostas; concubinas que convivem com a família do primeiro casamento; casais homossexuais; formação de famílias de mães; filhos adotivos; crianças que vivem com avós; dentre muitas outras formas de organização e formação familiar. Portanto, existem muitas formações familiares, além daquela da "casa grande e senzala" e "modernourbanizada".

A família camponesa também é exemplo que foge ao modelo modernourbanizada dos dias atuais, considerando que se constitui numa unidade econômica, tal como estudou Chayanov (1974), erguida a partir de uma constituição biológica (número de membros) da família que se articula produtiva, política e socialmente. As diferentes configurações de família camponesa não significam o rompimento da concepção de camponês elaborada por Chayanov (1974), em que a família está colocada no centro da organização produtiva da unidade econômica campesina; significam o reconhecimento da agricultura camponesa numa estrutura familiar que não esteja limitada à concepção tradicional de família. 
Observa-se que, apesar da modernização trazida pelo processo de industrialização e urbanização, a unidade econômica campesina está assentada na centralidade da família, comandada por um chefe, geralmente o pai. Enfim, a família camponesa ainda se constitui numa unidade econômica, ou seja, a unidade econômica campesina, a partir da qual giram as outras relações.

O comando exercido pelo chefe da família camponesa, por exemplo, não se dá sem resistências, conflitos e desencontros diversos. A saída de filhos jovens da unidade campesina com destino a cidade, principalmente, é motivada, dentre as razões econômicas e políticas, à centralização das decisões, feita geralmente pelo pai. A saída dos jovens é visualizada como uma possibilidade de independência e autonomia que, muitas vezes, não existe na família camponesa, ou seja, a saída de jovens do ambiente familiar camponês é entendida como parte da sua emancipação.

Outra característica da instituição familiar camponesa está relacionada à educação dos filhos, que é essencialmente doméstica e reproduz traços fortemente conservadores. Segundo Áries (1981, p. 228), a educação a partir de forças centrípetas (interna à família) foi sendo solapada com o progresso técnico e a emergência de uma educação centrífuga. Entretanto, ainda são fortes entre os camponeses as forças centrípetas com uma educação dos filhos privada e interna à família.

Nesse contexto, na educação familiar centrípeta, existem os castigos rigorosos dados aos filhos, inclusive com uso de violência, embora essas características não sejam exclusivas da família camponesa. Cândido (2003), ao estudar os "parceiros do Rio Bonito", afirma que "o certo é que atualmente castigam-se os filhos com severidade. Enquanto são menores, a tarefa cabe às mães; depois, aos pais, usando-se geralmente relhos, varas ou correia" (p. 314).

A educação dos filhos na família camponesa também possui particularidade motivada pela sua geografia porque, inserido no espaço rural, há dificuldade de acesso à educação escolar para além das primeiras letras. A vida camponesa e o trabalho em família não exigem conhecimentos mais amplos do que as experiências práticas e cotidianas. Assim, desde passado distante, fortaleceu-se uma educação em casa, bem como relações cada vez mais sentimentais de vínculos afetivos, como filhos que se desdobram na educação. 
A família camponesa, contraditoriamente, ainda reproduz tradições e traços do passado em relação à posse e propriedade da terra a ser herdada. Aliás, muitas famílias camponesas são formadas a partir de um fundamento econômico e não necessariamente de um casamento motivado pelo amor sexual. Os laços afetivos não são exclusivos no casamento camponês, pois essa é a união entre trabalho, representado pelo homem, e terra, representada pela mulher, conforme destaca Shanin (2008).

\begin{abstract}
No casamento do campesinato é diferente, ninguém está interessado em quem gosta de quem. Primeiro, são os pais que decidem quem vai casar. Como é que eles decidem? Muito frequentemente é o menino que tem cavalo que vai se casar com a menina que tem vaca. Ou, então, uma menina que tem terra se casa com menino com força de trabalho. Não é um casamento com sentido romântico, como o adotado pelas comunidades europeias, por exemplo. É um casamento entre cavalo, terra e a força de trabalho; esse é o casamento que existe. Quando isso acontece, podemos notar, por meio dos estudos dinâmicos, que tais propriedades se fortalecem repentinamente na maioria dos casos. (SHANIN, 2008, p.46).
\end{abstract}

A herança da terra a partir de laços familiares se constitui numa tradição do campesinato enquanto representação do passado existente nos dias atuais, bem como uma ordenação social familiar em que a mulher pouco participa das decisões sobre a terra. Tais características foram verificadas por Moura (1978), ao estudar os camponeses do bairro de São João da Cristina, no município de Maria da Fé, em Minas Gerais - área ocupada há cerca de 200 anos. Essa comunidade camponesa possui uma lógica específica de herança e passagem da propriedade da terra de geração em geração (sucessão familiar) que não é regulada somente pelo código civil brasileiro, esse, expressão do moderno. A autora verificou que complementarmente a "força da lei", de um lado, e a "consideração", de outro, constituem-se em elementos da lógica de herança camponesa.

Segundo a autora, as regras de herança camponesa não são observadas a partir do código de leis nacionais porque se ergue um código local em nome de acertos e arranjos familiares, visando à manutenção dos patrimônios territoriais familiares. Nessa regra, em que as relações familiares imperam, os homens se encarregam do negócio da terra, inclusive compra e venda das terras da irmã ou cunhada. A exclusão da mulher na herança da terra se justifica porque o trabalho na terra é um atributo do homem, sendo a mulher auxiliar à vida na terra, o que indica relações desiguais entre homens e mulheres.

As filhas mulheres nunca recebem parcelas de terra do pai, já que este provê de todo o "sustento", abrigadas como estão sempre sob o teto da "casa de morada" dos pais. Também não recebem "casa de morada" dentro da terra paternal, ao se casar, já que são seus maridos (e nesse quadro estão incluídos os sogros) que 
devem por em prática as regras. A virilocalidade resulta ali da posição específica da mulher face à produção e à propriedade da terra (a mulher não trabalha a terra, portanto não será cabeça de um empreendimento agrícola). E sem isto não se justifica que seja proprietária de uma parcela. (MOURA, 1978, 1978, p. 54).

O casamento nessa comunidade camponesa também não é mediado exclusivamente pelo amor romântico e erotismo, mas pela economia, semelhante aos estudos feitos por Shanin (2008), referidos anteriormente. O casamento é também uma transação, um negócio da terra entre o homem - cunhado ou marido, que é essencialmente masculino, bem como a junção da mão de obra auxiliar da mulher com a do homem.

A propriedade da terra está relacionada ao matrimônio sob o domínio do homem. Ao casar, o homem recebe do pai um pedaço do sítio. Essa herança da terra não ocorre com a mulher, pois ela não trabalha a terra, a não ser numa condição auxiliar. Assim, os vínculos familiares mediados pelo trabalho implicam em tratamentos desiguais a partir do sexo, visto que o homem recebe um pedaço de terra para trabalhar.

A autonomia do masculino vem com o acesso à terra concedida pelo pai. Já a autonomia da mulher vem a partir da sua capacidade de cuidar da casa. Dessa forma, o trabalho não remunerado fica para as mulheres e os negócios cabem ao homem. À mulher cabem os negócios somente para as pequenas sobras.

Ainda de acordo com Moura (1978), a forma de herança camponesa essencialmente familiar visa impedir a fragmentação da propriedade, assegurando a reprodução camponesa; não é apenas um ato de transferência de posse/propriedade da terra. A fragmentação da propriedade, embora haja, ocorre em vista da migração, por exemplo, às cidades ou outras regiões.

O que este capítulo se propõe a mostrar é como as regras "locais" de herança da terra desenvolvem uma lógica própria, que se baseia no conhecimento desse Código e cujo fim último é poupar ao máximo a integridade dos patrimônios territoriais. Visa, em última instância, assegurar a manutenção da área como camponesa, agindo como fator de reprodução da propriedade parcelar independente. (MOURA, 1978, p.47).

Apesar do exemplo de Moura (1978) para indicar a especificidade da herança e desigualdades na distribuição da terra entre camponeses, é importante observar que, na sua compreensão, as relações modernas ou atrasadas não estão relacionadas à temporalidade, mas, sim, à espacialidade. A autora considera que a forma de herança da comunidade estudada é parte de uma especificidade local (espaço) e não 
necessariamente da força do tempo histórico e do passado que persiste contemporaneamente. Nessa concepção, ela não coloca no centro da interpretação a dimensão histórica para compreender a especificidade da herança entre os camponeses estudados, mas, sim, as características espaciais, elementos centrais na explicação da transmissão da propriedade da terra.

Assim, verifica-se desigualdade na distribuição da terra da família camponesa a partir do sexo, cabendo ao homem o comando relativo ao trabalho na terra. À mulher cabem os trabalhos domésticos. Não é raro, por exemplo, mulheres estarem desinformadas e alheias à produção comercial no sítio camponês. Elas cuidam da produção destinada à alimentação feita no quintal da casa e geralmente comercializa apenas uma produção secundária e "acessória", o que para as mulheres é muito importante.

Nesse contexto também é exemplar a produção de leite. Quando destinada ao comércio, toda a organização produtiva está sob responsabilidade do homem. Mas, quando destinada ao auto-consumo da família, fica a cargo da mulher.

Entretanto, observa-se que a família camponesa não está "congelada" no tempo, pois se relaciona desigual e contraditoriamente à sociedade moderna industrial, ou seja, a família camponesa está inserida em contextos estruturais e superestruturais do modo capitalista de produção. A pressão à proletarização faz alguns membros da família migrarem em busca de trabalho temporário ou para centros urbanos a fim de garantir a existência da família camponesa, tal como demonstrou Garcia Jr. (1990), ao tratar das estratégias de reprodução camponesa de famílias nordestinas que migram em busca de trabalho para manutenção camponesa do restante da família. A saída de alguns membros da família garante a sua manutenção no sítio camponês, pois a atividade fora da terra enquanto "operário" aparece como complementar.

A força da família, tanto nos aspectos solidários e igualitários, quanto nas desigualdades, pode ser verificada e reconstituída nos assentamentos de reforma agrária, por exemplo. Embora geralmente os assentamentos sejam precedidos pelo estímulo ao coletivismo dos movimentos sociais, eles se constituem num momento de reconstituição da família e aproximação de parentes. O horizonte dos sem-terra acampados é conquistar a terra para se organizar enquanto família. Inclusive, não são raros os assentados que trocam de lotes para se aproximar de parentes. 
Nos assentamentos, de modo geral, são recuperados e reproduzidos traços de uma organização produtiva, cultural, social, dentre outras, que tem por base a família camponesa. A partir do assentamento são recriadas sociabilidades solidárias, igualitárias, comunitárias e emancipatórias das famílias que estavam sendo erodidas no processo de urbanização-industrialização, no qual a família foi deixando de ser hegemonicamente uma unidade produtiva. Assim, são recuperadas (ou mantidas) nos assentamentos características familiares camponesas; são ressignificadas sociabilidades familiares a partir de experiências vividas fora da vida camponesa.

As características mantidas, recuperadas ou ressignificadas nos assentamentos, ora são questionadoras, ora são reforçadoras de estrutura e superestrutura de dominação, opressão, subordinação etc. Portanto, de um lado são reproduzidas e mantidas relações familiares de dominação, autoritarismo e opressão, e de outro, são recriadas relações humanizadas, solidárias, comunitárias e gestos virtuosos e de grandeza humana.

Essas características são vividas não apenas nos assentamentos, mas fazem parte do conjunto da agricultura camponesa. Por isso, os camponeses, vivendo no contexto social em que estão inseridos, reproduzem desigual e contraditoriamente conflito e harmonia, opressão e libertação, solidariedade e egoísmo, dentre outras contradições. Essas características permitem afirmar que os camponeses são negadores e conservadores de relações sociais de produção.

\section{Considerações finais}

A partir das questões apontadas é possível chegar a um conjunto de verificações sobre as características contraditórias do campesinato. Os camponeses negam e reproduzem relações de dominação, enfim, apresentam traços conservadores e críticos às estruturas e superestruturas sociais.

Verifica-se na esfera política que os camponeses possuem capacidade de negar e questionar estruturas de dominação, como no caso da derrubada de cercas latifundiárias do agronegócio a partir de sua organização nos movimentos sociais, principalmente. Observa-se ainda que os camponeses são capazes de ações de solidariedade, reproduzindo valores comunitários, meio pela qual garantem a sua existência num contexto adverso. Mas, contraditoriamente, eles reproduzem relações de dominação na 
tomada de decisões conservadoras, sobretudo na política eleitoral, posicionando-se a favor daqueles que lhes oprimem e contrários à reforma agrária.

Os camponeses também assumem posição conservadora no interior da família. Aliás, a instituição familiar se constitui em base nuclear da existência camponesa. Os camponeses praticam no meio familiar atitudes autoritárias ou machistas. Mas, a família camponesa é capaz de gestos virtuosos e de grandeza humana.

Eis, pois, as contradições camponesas.

\title{
Notas
}

\begin{abstract}
1 A capacidade produtiva dos camponeses é verificada a partir de dados oficiais da área cultivada, produção e financiamentos para investimento e custeio de lavouras. Os pequenos agricultores, dispondo de apenas $24,3 \%$ da área total de terras do país, conforme o IBGE (2006), e de R\$ 26 bilhões em recursos financeiros (Plano Safra da Agricultura Familiar 2013-2014), são responsáveis por 33\% do PIB (Produto Interno Bruto) agropecuário. Eles produzem $100 \%$ das verduras, $87 \%$ de mandioca, $70 \%$ do feijão, $59 \%$ de suínos, $58 \%$ do leite, $50 \%$ de aves, $46 \%$ do milho, $38 \%$ do café, dentre outros exemplos.

${ }^{2}$ Em 2014, o candidato a governador de São Paulo, Geraldo Alckmin, assumidamente descomprometido com a reforma agrária e luta camponesa, recebeu nas eleições daquele ano expressiva votação de camponeses assentados, motivo inclusive de orgulho do candidato pelo "acerto" do seu programa agrário para o Estado de São Paulo.

${ }^{3}$ A CPT (comissão pastoral da terra) publica anualmente, desde 1985, o documento "Conflitos no Campo - Brasil”, que faz um levantamento e caracterização das diversas violências sofridas pelos camponeses e indígenas no Brasil.
\end{abstract}

\section{Referências}

ABRAMOVAY, R. Paradigmas do Capitalismo Agrário em Questão. São Paulo: Hucitec. 1992.

ÁRIES, P. História Social da Criança e da Família. Tradução de Dora Flasksman. Rio de Janeiro: LTC - Livros Técnicos e Científicos Editora S.A. 1981.

CALDART, R. Pedagogia do Movimento Sem Terra. Petrópolis: Vozes. 2000.

CÂNDIDO, A. Os Parceiros do Rio Bonito. São Paulo: Duas Cidades, Editora 34. 2003.

CHAYANOV, A. V. La Organización de la Unidad Económica Campesina. Buenos Aires: Nueva Visión.1974.

CORRÊA, M. Repensando a família patriarcal brasileira. Cad. Pesq., São Paulo, (37): p. 5-16, maio/1981.

ENGELS, F. A origem da família, da propriedade e do estado. Rio de Janeiro: civilização brasileira. 1984. 
GARCIA JR. A.R. O Sul: caminho do roçado. São Paulo: Marco Zero. 1990.

FUKUI, L.F.G. Sertão e Bairro Rural. São Paulo: Atica. 1979. HARNECKER, M.

Tornar Possível o Impossível: A Esquerda no Limiar do Século XXI. São Paulo, SP: Paz e Terra, 2000.

HOBSBAWM, E. Pessoas extraordinárias: resistências, rebelião e jazz. São Paulo: Paz e Terra, 1999.

LUXEMBURGO, R. A acumulação do capital. São Paulo: Nova cultural. 1988.

MARTINS, J. S. Caminhada no Chão da Noite. São Paulo: Hucitec. 1989. Os Camponeses e a Política no Brasil. 4 ed., Petrópolis: Vozes. 1990. A sociedade Vista do Abismo. Petrópolis: Vozes, 2002.

O Poder do Atraso. São Paulo: Hucitec. 1994.

A modernidade do "passado" no meio rural. In: NAVARRO, Z. et. al. O mundo Rural no Brasil do Século 21. Brasília: Embrapa. 2014.

MITRANY, D. Marx contra o camponês. Rio de Janeiro: Ed. Ipanema. 1957.

MOURA, M. M. Os herdeiros da terra. São Paulo: Hucitec. 1978.

OLIVEIRA, A. U. Agricultura e indústria no Brasil. Campo-Território: revista de geografia agrária, v.5, n.10, p. 5-64, ago. 2010. p.5-64.

Agricultura Camponesa no Brasil. São Paulo: Contexto. 1991.

ROOS, D. Contradições na construção dos territórios camponeses no Centro-Sul paranaense: territorialidade do agronegócio, subordinação e resistências. Presidente Prudente: doutorado em Geografia. Unesp/PP. 2015.

SANTOS, J. V. T. Colonos do Vinho. São Paulo: Hucitec. 1978.

SCHERER-WARREN, I. e KRISCHKE, P.J (orgs.). Uma revolução no cotidiano? São Paulo: Brasiliense. 1987.

Cidadania sem fronteiras: ações coletivas na era da globalização. Hucitec, 1999.

SHANIN, T. Lições camponesas. In: PAULINO, E.T. e FABRINI, J.E. (Orgs.)

Territórios em disputa. São Paulo: Expressão Popular. 2008.

SILVA, J. G. A nova dinâmica da agricultura brasileira. Campinas: UNICAMP. 1996. 
SILVA, M. A. M. O código do sertão e as várias faces da violência. In: SANTOS, J.V. T. Violência em tempo de Globalização. São Paulo: Hucitec. 1999.

TERUYA, M. T. A família na historiografia brasileira. Bases e perspectivas teóricas. Digitado. 1999.

VIANNA, L.W. O moderno, o atraso e a esquerda. www.humanitas.br. 2014. Acesso 20 de outubro de 2014.

WOLF. E. Guerras Camponesas no Século XX. Melhoramentos: São Paulo. 1984.

Recebido em 27/06/2018.

Aceito para publicação em 30/01/2019. 